will subsequently amplify by a factor averaging about 2.0 per iteration. This amplification has nothing to do with computers and would occur even if the values were expressed exactly as rational fractions. Thus, during our 119 tabulated iterations, the errors multiply by about $2^{119}$, or $10^{36}$. To have determined $X_{119}$ accurately to four decimal places, we should have carried our computations during the first few iterations to $\mathbf{4 0}$ places. This precision exceeds "double precision" on most computers, and a special triple or multiple precision routine would have been needed.

Such a routine is entirely feasible. However, should we wish to determine $X_{1,000,000}$ to four places, we would have to carry the first computations to about 300,000 places! The whole job would require between $10^{13}$ and $10^{14}$ double-precision multiplications, or about a year on a fast computer, and it is doubtful that anyone would see fit to use the computer for this purpose.

What makes our run of $1,000,000$ steps meaningful even though the step-by-step values are wrong and what makes climate modeling meaningful even though the dayby-day weather sequence is fictitious, is that the statistical (or climatological) properties of the values are virtually independent of the computer. To illustrate this feature we have made two runs, each of $1,000,000$ steps, beginning in each run with $X_{0}=1 / 2$. In the first run we used ordinary double precision (about 17 decimal places), while in the second we used a procedure which decreased the precision by about one place, thereby simulating a smaller computer. We found that $X_{n}$ changed sign 56,762 times during the first run and 56,652 times during the second, while the standard deviation of $X_{n}$ was 0.5369 in the first run and 0.5373 in the second. However, the correlation coefficient between the two runs was only 0.0005 . Clearly the runs bchaved like two large samples chosen independently from the same population.

Concerning Dr. Fliri's second comment, there is certainly an enormous number of values of $X_{0}$ leading to exactly the same value of $X_{119}$, since $X_{119}$ is a polynomial of degree $3^{119}$, or about $10^{57}$, in $X_{0}$. This conclusion has nothing to do with computers. When, however, one attempts to find some of these values of $X_{0}$ numerically, the answers depend upon the computer. In fact, the correct values of $X_{0}$ are so densely packed that virtually any other value of $X_{0}$ could be mistaken by the computer for one of them. Thus, until the computer is specified, the probability of "forecasting"' a given value for $X_{119}$ is nearly independent of $X_{0}$.

\author{
EDWARD N. LORENZ \\ Department of Meteorology \\ Massachusetts Institute of Technology \\ Cambridge, Massachusetts 02139
}

\title{
Comment on "The Tunica Hills, Louisiana-Mississippi: Late Glacial Locality for Spruce and Deciduous Forest Species" by Paul A. Delcourt and Hazel R. Delcourt
}

While the botanical aspects of a paper by Delcourt and Delcourt (1977) represent a much needed and most welcome update of information on the Tunica Hills Pleistocene plant fossils, I must take strong exception to the stratigraphic, geomorphic, and consequent paleoclimatic conclusions. It appears that the basis for mapping two sets of depositional stream terraces in the creek valleys, regarded as Sangamon Interglacial and late glacial-Holocene, respectively, was the ecological difference between the "warm-temperate" Wilcox Bluff flora and the "cool-temperate" Tunica Bayou-Percy Bluff floras with two boreal taxa. At Wilcox Bluff, the plant assemblage occurs higher in the alluvial sequence above the stream bed than at the other two locations. Neither this 
paper, nor P. Delcourt's original masters thesis (1974) provided any sedimentological or morphological evidence for these two separate terraces. Nor did my field work, conducted over the past decade mostly in the Little Bayou Sara area, turn up any convincing clue for such an argument. Good outcrops in the Quarternary units are rare even along the creeks and nonexistent further from them. No documentation has been offered for any of the quoted drill data that would support these statements. Because of the extensive loess cover of uneven thickness in most of the study area, one is at a complete loss to understand how the boundaries separating the two assumed terraces and delineating them against the pre-Quaternary units were drawn on their geological map in the various creek valleys. Published topographic maps certainly do not offer evidence in this respect, either.

My objection to the proposed late glacialHolocene age of the fossiliferous alluvial units, designated by the Delcourts as "Terrace 1" sediments, is fourfold: (1) The loess cover appears to be undisturbed and continuous over most of these units. It is fresh-looking and does not seem to have been involved in colluvial redeposition, as claimed in the paper (p. 222), or in slumping to any significant extent. A gastropod shell age from the top of the loess sequence at Tunica $(21,570 \pm 310$ yr BP; Otvos, 1975) comes probably from within a few millenia of the cutoff date for the cessation of loess deposition, due to general climatic amelioration in southern Louisiana and Mississippi. Further north, the youngest loess date at Vicksburg was $17,850 \pm 380$ yr BP (sample OX-185; Snowden and Priddy, 1968, pp. $120-121$ ) and not 12,500 yr as implied by the Delcourts (p. 222). Loess deposition lasted slightly beyond the latter date in Illinois (Willman and Frye, 1970, pp. 66, 124) but most likely did not even approach it in southern Louisiana and Mississippi. This means that the fossiliferous Tunica Hills alluvial sequence was deposited probably prior to $22,000 \mathrm{yr}$ BP.
(2) All five radiocarbon dates used in the Delcourt paper (1977) appear to have been contaminated and, therefore, are unreliable. Two dates $(12,740$ and 12,600 yr BP) from a unit associated with the Tunica Bayou Mammut americanum (American mastodon) find and overlain by loess (Levin et al., 1965) are much too young when compared with the mentioned loess ages. I provided $P$. Delcourt with the youngest date in this paper $(3457 \pm 366 \mathrm{yr}$; No. 69-363, analyzed at LSU, July 1970) 5 years ago, with the warning (unheeded) that it is unrealistic and probably completely useless. The date came from a carbonized branch fragment in an outcrop, referred to by Delcourt (1974, $\mathrm{p}$. 115, 173; 1977, p. 227, Fig. 5) as "Percy Bluff"' (SW 1/4, sec. 74, T. 1 S., R. 4 W.), about $7 \mathrm{~m}$ below the top surface of the bluff. It was derived from consolidated sandy silt layers that contain occasional pyritized wood fragments. Later, the unit was recognized as part of the Late Miocene Pascagoula, or an equivalent Tertiary formation. [The "original" Percy Bluff outcrop, site of the earlier fossil collection, is located upstream, on the opposite, west bank of Little Bayou Sara (Fisk, 1938, p. 17); Brown (1938) also quotes different section numbers for his outcrop location.]

Both remaining dates $(7240 \mathrm{yr} \mathrm{BP}$, Bender and others, 1967, pp. 542-543; and 5295 yr BP, Delcourt and Delcourt, 1977) came from this very outcrop, probably from the same 1- to 1.25 -m-thick lense of plant fragments and detritus, located above the Miocene beds. In view of my date and the thickness of the alluvial and loess sequence overlying the other two sample spots that implies a substantial period of sediment accumulation in any event, it is safe to assume that all three samples were contaminated by organic-rich soil solutions that drastically altered the original radiocarbon content.

(3) While alluviation is expected to have happened during the rise of the Holocene base level, the problem of accepting creek aggradation to the surface levels of assumed 
"Terrace 1," 6.5-9 $\mathrm{m}$ above the present creek levels (Delcourt, 1974, pp. 64-69; Delcourt and Delcourt, 1977), only 4000 to $5000 \mathrm{yr}$ ago is considerable, to say the least. Equally baffling is the task of explaining the underlying reasons for a swift creek entrenchment of equal magnitude that is assumed to have suddenly followed such an alluviation in the past three to four millenia. This entrenchment implies an extensive Late Holocene-recent uplift in the Tunica Hills. Recent geodetic leveling in the area (Holdahl and Morrison, 1974, Fig. 5) indicated not an uplift but a current subsidence of approximately $1.5 \mathrm{~mm} / \mathrm{yr}$.

Delcourt (1974, p. 85, not repeated in the 1977 paper) explained the entrenchment of his "Terrace 1" by an eastward shift of the Mississippi River $\mathbf{4 0 0 0}$ yr ago that shortened its eastern tributaries and steepened their gradients. This is an unsatisfactory theory: Although during such shift the overall tributary gradients did steepen, creek segments within the Tunica Hills area remained graded to the level of the same Mississippi floodplain, their local base level. Only tectonic or eustatic base level changes could account for this kind of terrace entrenchment.

(4) Recently acquired preliminary data, involving radiocarbon dating of humusextracted wood and cellulose material (to minimize or eliminate the chance of postdepositional radiocarbon contamination) in another Little Bayou Sara outcrop reconfirmed the general Wisconsin age interpretations of Fisk and Brown (1938). The location, $7 \mathrm{~km}$ (4.3 mile) NNW of the Percy Bluff sites, is at St. James Church, south of Pinckneyville, Mississippi. The samples came from what is interpreted to be the same sandy alluvial sequence, overlain by loess. On the Delcourts' map the alluvium at this outcrop is shown as part of "Terrace 2" (Sangamon). Several finite dates (Otvos, in preparation) indicate late Altonian or early Farmdalian ages for this sequence. This does not exclude the possibility that other parts of the Tunica Hills Pleistocene alluvial-lacustrine sequence formed somewhat earlier, even during warmer periods, as the Wilcox Bluff flora may indicate. However, on the basis of the evidence available thus far, the assignment of the Wilcox Bluff and other deposits to the Sangamon Interglacial does not appear to be justified.

\section{REFERENCES}

Bender, M. M., Bryson, R. A., and Baerreis, D. A. (1967). University of Wisconsin radiocarbon dates III. Radiocarbon 9, 542-543.

Brown, C. A. (1938). The flora of Pleistocene deposits in the western Florida Parishes, Western Feliciana Parish and East Baton Rouge Parish, Louisiana. Louisiana Department of Conservation Geological Survey Bulletin 12, 59-96, 121-129.

Delcourt, P. A. (1974). "Quaternary Geology and Paleoecology of West and East Feliciana Parishes, Louisiana, and Wilkinson County, Mississippi." M.S. Thesis, Louisiana State University, Baton Rouge, La.

Delcourt, P. A., and Delcourt, H. R. (1977). The Tunica Hills, Louisiana-Mississippi: Late glacial locality for spruce and decious forest species. Quaternary Researe 7, 218-237.

Fisk, H. N. (1938). Pteistocene exposures in western Florida Parishes of Louisiana. Louisiana Department of Conservation Geological Survey Rulletin 12, 3-25.

Holdahl, S. R., and Morrison, N. L. (1974). Regional investigations of vertical crustal movements in the U.S. using precise relevelings and mareograph data. Tectonophysics 23, 373-390.

Levin, B., Ires, P. C., Oman, C. L., and Rubin, M. (1965). U.S. Geological Survey Radiocarbon Dates VIII. Radiocarbon 7, 375.

Otvos, E. G., Jr. (1975). Southern limits of Pleistocene loess, Mississippi Valley. Southeastern Geology 17, 27-38.

Snowden, J. O., Jr., and Priddy, R. R. (1968). Geology of Mississippi loess. Mississippi Geological, Economic and Topographical Survey Bulletin 111, 13-203.

Willman, H. B., and Frye, J. C. (1970). Pleistocene stratigraphy of Illinois. Illinois State Geological Survey Bulletin 94, 204.

ERvin G. Otvos, JR. Gulf Coast Research Laboratory Ocean Springs, Mississippi 39564 